\title{
A New Species of Doryopteris from Surinam
}

CARL U. KRAMER AND ROLLA M. TRYON, JR.

Reprinted from Annals of the Missouri Botanical GardeN 42:213-214. September, 1955 


\section{A NEW SPECIES OF DORYOPTERIS FROM SURINAM*}

KARL U. KRAMER AND ROLLA M. TRYON, JR.

In the course of examination of specimens in the fern collection of the Botanisch Museum en Herbarium, Utrecht, the senior author discovered a specimen of Doryopteris that seemed to be different from any species treated in the junior author's revision of the genus'. Further examination has proved this to be the case and it is here described as new.

DORYOPTERIs conformis, spec. nov.

Rhizoma modice crassum breviter repens, squamis elongatis angustissimis dense vestitum, partium hyalinarum cellulis latitudine maxime partem quintum longitudinis aequantibus; stipes obscurus laevis vel leviter rugosiusculus, fasciculis vascularibus duobus; lamina fertilis sterili similis coriacea, venatio libera; sterilis suborbicularis-quinquangularis, profunde bipinnatifida; fertilis conformis, profunde bi- vel tripinnatifida; receptaculum intramarginale plus minusve continuum; sporangia breviter pedicellata.

Typus: Gonggrijp \& Stahel (B. W.) 5699; Surinam: Mt. Hendriktop, alt. 1080 m.; moist, sunny rocks; in Herb. Utrecht.

Rhizome moderately stout, short-creeping; scales of the apex of the rhizome very long and narrow, the cells of the hyaline portions at least five times as long as broad; stipe dark purple to black, naked or slightly scaly at the base, glabrous, smooth or minutely and irregularly roughened, with two vascular bundles at the base, terete; fertile and sterile blades similar, without proliferous buds, coriaceous; sterile leaf about $25 \mathrm{~cm}$. long; blade $7 \mathrm{~cm}$. long, suborbicular-pentagonal, deeply bipinnatifid with about 12 oblong, broadly rounded, entire or partially crenulate ultimate lobes; margin with a pale brown cartilaginous border; venation free; hydathodes prominent on the upper surface; fertile leaf about $25 \mathrm{~cm}$. long; blade about $8 \mathrm{~cm}$. long, suborbicular-pentagonal, deeply bi- to tripinnatifid, with numerous ultimate segments; primary segments broadly decurrent and surcurrent, the bases forming wings along the rachis with symmetrically concave sides; ultimate segments oblong-lanceolate, narrowly rounded, entire; soral lines continuous around the sinuses; sporangia short-stalked, i.e. the stalk somewhat shorter than capsule (which is $340-360 \mu$ long), borne on a more or less continuous vascular commissure; spores subglobose, triplanate, slightly rugose, pale yellow-brown, about $55 \mu$.

Doryopteris conformis is most closely related to $D$. lomariacea from which it differs in the non-dimorphic fertile and sterile leaves, the segments of the fertile being much broader than in $D$. lomariacea, in the short-stalked sporangia and coriaceous texture of the blades; in D. lomariacea, the sporangia are long-stalked and the leaf-tissue is herbaceous.

This species is notable in that it is the only local endemic in the genus outside of southeastern Brazil. However, the Guiana Highlands represent a weak sec-

${ }^{1}$ Tryon, Rolla M. A revision of the genus Doryopteris. Contr. Gray Herb. 143:1-80. 1942.

*Issued November 17, 1955. 
ondary center for the genus in South America. This is the sixth species known from there, not including the widespread and somewhat doubtfully allied $D$. concolor; a concentration of species exceeded only in the southeastern Brazilian Highlands. It is also significant that all the other five species, $D$. lomariacea, sagittifolia, collina, varians, and pedata var. multipartita are variously disjunct between southeastern Brazil and the Guiana Highlands. Whether $D$. conformis represents a local offshoot of $D$. lomariacea or whether it was evolved, as all other Guiana species evidently were, in southeastern Brazil and migrated via the Andes to the Guianas, can only be determined if it is eventually discovered in Brazil.

\section{Explanation of Plate}

PLATE 30

Fertile and sterile leaf of Doryopteris conformis, from type. $\times 2 / 3$. 